\title{
Bioavailability of Iron and Related Components in Cooked Green Leafy Vegetables Consumed in Cameroon
}

\author{
Rachel Fai Nomkong1, Richard Aba Ejoh ${ }^{*}{ }^{*}$, Romelle Feumba Dibanda ${ }^{2}$, Medoua Nama Gabriel ${ }^{2}$ \\ ${ }^{1}$ Department of Food and Bioresource Technology, College of Technology, University of Bamenda, Bambili, Cameroon \\ ${ }^{2}$ Centre for Food and Nutrition Research, IMPM, Yaounde, Cameroon \\ Email: *ejohrab@yahoo.com
}

How to cite this paper: Nomkong, R.F., Ejoh, R.A., Dibanda, R.F. and Gabriel, M.N. (2019) Bioavailability of Iron and Related Components in Cooked Green Leafy Vegetables Consumed in Cameroon. Food and Nutrition Sciences, 10, 1096-1111.

https://doi.org/10.4236/fns.2019.109079

Received: August 19, 2019

Accepted: September 13, 2019

Published: September 16, 2019

Copyright $\odot 2019$ by author(s) and Scientific Research Publishing Inc. This work is licensed under the Creative Commons Attribution International License (CC BY 4.0).

http://creativecommons.org/licenses/by/4.0/

\begin{abstract}
Green leafy vegetables (GLVs) are a potential source of iron to combat iron deficiency in iron deficient population. The aim of this study was to determine the bioavailability of iron in seven species of leafy vegetables (Solanumscrabrun, Venonia amygdalina, Cucurbita maxima, Amarathus hybridus, Colococia esculenta, Solanum macrocarpon and Telfairia occidentalis) consumed in Bamenda, Cameroon. A survey was carried out in 70 households in Bamenda, Cameroon to determine methods of preparation of these green leafy vegetables. Iron, antinutrients and vitamin C levels were determined using standard methods and the bioavailability of iron was determined using an in vitro dialys ability method. The vegetables used for the study were cooked with the addition of tomatoes, peanuts, melon seeds and soybean seeds. The loss of iron in GLVs was as a result of dilution caused by addition of the principal ingredients. The $V$. amygdalina cooked with soybean contained the highest level of iron $(128.28 \mathrm{mg} / 100 \mathrm{~g})$. The $S$. scrabrum cooked with tomatoes had the highest Total phenolic coumponds of $0.91 \mathrm{~g} / 100 \mathrm{~g}$; the C. esculenta recorded the highest with values ranging between $0.14-0.35$ $\mathrm{g} / 100 \mathrm{~g}$; the $C$. maxima cooked with soybean recorded the highest oxalate level $(6.46 \mathrm{~g} / 100 \mathrm{~g})$; and the vegetables cooked with melon seeds recording the highest in phytatelevels $(70-1.63 \mathrm{~g} / 100 \mathrm{~g})$. Vitamin C levels were highest in the $S$. macrocarpon cooked with tomatoes $(199.96 \mathrm{mg} / 100 \mathrm{~g})$. Iron bioavailability was highest in $A$. hybridus cooked with tomatoes (28.09\%). The iron bioavailability negatively correlated with phytates and positively with vitamin C. GLV consumed in Bamenda are good sources of iron whose bioavailability can be improved by using tomatoes in cooking.
\end{abstract}

\section{Keywords}

Green Leafy Vegetables, Iron Bioavailability, Cooking, Antinutrients, Vitamin C 


\section{Introduction}

Iron deficiency is one of the most devastating and widespread micronutrient deficiencies, affecting about a third of the world's population [1]. It is the most prevalent cause of anaemia [2]. Its other consequences include impaired cognitive development, increased susceptibility to infection [3], increased risk of morbidity in children, unfavorable pregnancy outcomes and decreased work productivity in adults [4] (WHO, 2000).

Animal-based foods are better sources of iron, but due to their higher costs, people with low incomes get iron from plant-based foods [5]. Among these plant based foods, green leafy vegetables (GLVs) have been shown to be rich sources of iron [6]. Due to their low costs and wide availability, they can serve as an important source of iron for low income populations [5]. Unfortunately, they contain high levels of antinutritional factors such as phytates and polyphenols, which chelate iron and make it unavailable for absorption, thus decreasing its bioavailability [7]. However, heat treatment can reduce the levels of antinutritional factors in vegetables, and so increase the bioavailability of iron.

In Cameroon, a number of studies have been carried out to determine the nutrient composition of boiled GLVs [8] [9] [10].The bioavailability of carotenoids in some lesser-known vegetable recipes has also been studied [11] [12] [13]. However, there is limited information on the bioavailability of iron in Cameroonian vegetable recipes [14]. This limits their use in the fight against iron deficiency [15]. Given the above, this study was carried out to evaluate the bioavailability of iron in some GLVs consumed in Bamendain the North West Region (NWR) of Cameroon.

\section{Materials and Methods}

\subsection{Study Design}

In order to identify common indigenous GLVs consumed in Bamenda, a survey as carried out in three markets located within Bamenda (Bamenda Food market, Nkwen market and Bamenda main market). To describe the recipes and cooking methods used in the preparation of GLVs, a pretested questionnaire was administered to 70 randomly selected households in Bamenda in August 2017. Only those principally involved in cooking food for a the households provided information for the questionnaire.

\subsection{Selection of Recipes, Preparation of the Vegetables}

The ingredients included in the final recipes used for the study were ingredients used by at least $50 \%$ of surveyed households. Preparation and cooking methods employed for the study were also those used by at least 50\% of the surveyed population. Earlyin the morning, about $4 \mathrm{~kg}$ of the GLVs were randomly obtained from some farmlands in mile 5 Nkwen, Bamenda, and were immediately transported in open bags to the Food Science laboratory at the University of Bamenda. All other ingredients used in the cooking of the vegetable (bouillon 
cubes-4 g, salt- $6 \mathrm{~g}$, tomato-100 g for tomato sauce, onion 50 - $60 \mathrm{~g}$, peanut, melon seeds, soybean seeds and cooking oil) were purchased from the local market.

After harvesting each GLV, the leaves were destalked, rinsed under tap water and left for $20 \mathrm{~min}$ to drain, and then subjected to different processing conditions. The drained vegetable was divided into 6 lots of about $600 \mathrm{~g}$ each. One lot was left to dry at $50^{\circ} \mathrm{C}$ in an electric oven (DGH, model 108,090) for $24 \mathrm{~h}$ while the other lots were mixed together, washed, sliced and boiled. Solanium scrabrum and Colococia esculenta were not sliced before boiling.

The sliced vegetables were added to about $3 \mathrm{~L}$ of boiled water and left to boil for about 5 - 15 minutes. Before being boiled, Vernonia amygdalina sliced leaves were hand washed to reduce the level of bitterness as described by survey participants. In the case of $S$. Scabrum, the leaves were boiled with water for $15 \mathrm{mi}$ nutes while $C$. escuelenta leaves were boiled for $45 \mathrm{~min}$ with the addition of about $0.5 \mathrm{~L}$ of water. The boiled vegetables were allowed to drain in a strainer for $20 \mathrm{~min}$, and then shared into 5 equal lots. One of the lots was allowed to dry in the oven at $50^{\circ} \mathrm{C}$ for $24 \mathrm{~h}$, while the other lots were processed based on the survey findings on recipes, preparation and cooking methods. In the cooking of the vegetables with "egusi", peanut and soy bean (100 - $150 \mathrm{~g}$ in each case), $400 \mathrm{~g}$ of the boiled vegetable was used and for tomatoes $100 \mathrm{~g}$ was used. In all cases seasoning (6 $\mathrm{g}$ salt and $4 \mathrm{~g}$ Cube) was added as well as unrefined palmoil (40 $\mathrm{g}$ ) and onions (40 - $60 \mathrm{~g}$ ). The cooking process was as discribed in Chagomoka et al. [16].

After the vegetables were cooked, they were allowed to cool to room temperature before drying. The samples (raw, boiled and four preparations for each vegetable species) were spread thinly on aluminum foil trays and dried at $50^{\circ} \mathrm{C}$ for $24 \mathrm{~h}$. They were then milled using an electric blender and sieved using a 500 $\mu \mathrm{m}$ mesh pore size sieve (Fisher scientific, AFNOR NFX11804), packaged in polythene bags and transported to the Food and Nutrition Research Center at the Institute of Medical Research and Medicinal Plant studies (IMPM), Yaounde Cameroon, for analysis.

\subsection{Chemical Analysis}

\subsubsection{Total iron Content Determination}

Iron contents in all the samples were determined after wet digestion with a mixture of nitric, sulphuric and hydrochloric acid using Atomic Absorption Spectrophotometer (AAS aalae spectrophotometer S11) [17].

\subsubsection{Bioavailability and Ionizable Iron Estimation}

The in vitro bioavailability of iron from the leafy-vegetables samples were determined [18] and the estimation of ionizable iron in the filtrates estimated by adaptation of the $\alpha$-dipyridyl method [19]. Duplicate aliquots (5 $\mathrm{ml}$ ) of the filtrates were taken and the volume in one set was made up to $15 \mathrm{ml}$ and served as the extract blank. The other aliquot was treated with $1 \mathrm{ml}$ of $10 \%$ hydroxylamine hydrochloride, $5 \mathrm{ml}$ of acetate buffer $\mathrm{pH} 4.2,2 \mathrm{ml}$ of $0.1 \%$ of $\alpha$, $\alpha$-dipyridyl reagent, and made up to $15 \mathrm{ml}$ with water. The colour developed was measured at $510 \mathrm{~nm}$ in the Spectronic S 11 against a reagent blank. Iron standards (1 - 15 
$\mathrm{mg}$ ) were simultaneously run in the assay. The ionizable iron content in the sample was derived after subtracting the optical density of the extract blank from that of the sample.

The levels of phytates [20], oxalates [21], phenolic compounds [22], saponin [23] and tannins [24] were determined for the samples as described in the cited references. Vitamin $\mathrm{C}$ was also determined according to the method described by AOAC [21].

\subsection{Statistical Analysis}

All chemical analyses were done in triplicates. STATISTICA version 10.0 was used for statistical analysis. One-factor analysis of variance (ANOVA) was used to test for differences among means for the raw and cooked vegetables. Tukey's post hoc multiple test was applied to determine significant differences between specific means and Pearson's correlation analysis was used for associations between antinutrients and bioavailable iron in the raw and cooked green leafy vegetables. Values of $\mathrm{p}<0.05$ were considered statistically significant for all analyses.

\section{Results and Discussion}

\subsection{Vegetable Consumption and Cooking Techniques}

Results of survey in the markets as seen in Table 1 show that there were seven species of GLVs mostly consumed in Bamenda (Solanum scrabrum, Vernonia amygdalina, Colocasia esculenta, Cucurbita maxima, Telfairia occidentalis, Amaranthus hybridus and Solanum macrocarpon) with two consumed by all the household that is $S$. scrabrum and V. amygdalina.

As shown in Table 2, S. scrabrum was prepared using only three principal ingredients (tomatoes, melon seeds and peanuts), while all the other leafy vegetables were prepared using 4 major ingredients (tomatoes, pumpkinseeds, peanuts and soybeans). Tomato was the most used ingredient in this region for the preparation of vegetables with $82.9 \%$ of the housholds using it in the prepation of $A$. hybridus. This population used pumpkin seeds mostly in the prepation of $V$.

Table 1. Names and consumption frequency for the seven selected green leafy vegetables.

\begin{tabular}{ccccc}
\hline $\begin{array}{c}\text { Scientific } \\
\text { name }\end{array}$ & $\begin{array}{c}\text { Common } \\
\text { name }\end{array}$ & $\begin{array}{c}\text { Local } \\
\text { names }\end{array}$ & $\begin{array}{c}\text { Households } \\
\text { consuming (\%)* }\end{array}$ & $\begin{array}{c}\text { Households } \\
\text { consuming at least } \\
\text { once a week (\%) }\end{array}$ \\
\hline S. scabrum & Huckleberry & NjamaNjama & 100 & 71.4 \\
V. amygdalina & Bitter herbs & Bitter leaf & 100 & 40.0 \\
C. esculenta & Taro leaves & Cocoleaf & 78.6 & 11.4 \\
C. maxima & Pumpkin leaves & Pumpkin & 74.3 & 15.7 \\
T. occidentalis & Fluted pumpkin & Okohobong leaf & 61.4 & 21.4 \\
A. hybridus & Green amaranth & Green & 82.9 & 41.4 \\
S. macrocarpon & African egg plant & Anchia leaf & 60 & 22.9 \\
\hline
\end{tabular}

${ }^{\star}$ Consumption in different recipes. 
Table 2. Frequency of use of major ingredients in the preparation of green leafy vegetables expressed as percentage.

\begin{tabular}{ccccc}
\hline Green leafy vegetables & Tomato & Pumpkin seeds & Peanuts & Soybean \\
\hline A. hybridus & 82.9 & 17.1 & 55.7 & 12.9 \\
C. esculenta & 31.4 & 18.6 & 12.9 & 7.1 \\
S. scrabrum & 67.1 & 58.6 & $32.9)$ & 0 \\
V. amygdalina & 72.9 & 67.1 & 84.3 & 35.7 \\
C. maxima & 74.3 & 52.9 & 62.9 & 30 \\
T. occidentalis & 17.1 & 60 & 12.9 & 10 \\
S. macrocarpon & 12.9 & 30 & 11.4 & 8.6 \\
\hline
\end{tabular}

amygdalina leaves (67.1\%) followed by $T$. occidentalis (60\%). Fewer persons used this ingredient in the prepation of the other vegetables. Peanut was principally used in Bamenda for the prepation of $V$. amygdalina leaves (84.3\%). It was also used though to a lesser extent in the prepation of other vegetables with $A$. hybridus (55.7\%) being the most perculiar. Soybean was used to substitute peanuts in $V$. amygdalina by $35.7 \%$ of those surveyed. Fewer people used it as an ingredient for the other vegetables. Leaks, onions, galic, ginger, crayfish, vegetable oil, and "kanwa" (natron) were used in the preparation of these vegetables as minor ingredients.

\subsection{Influence of Boiling and Processing on Iron Levels}

The effect of boiling and processing on the level of iron in each of the GLVs is presented in Table 3. The iron level in the raw GLVs ranged from $45.90 \pm 1.73$ in C. esculentato $180.03 \pm 3.92 \mathrm{mg} / 100 \mathrm{~g}$ in $S$. macrocarpon on DW basis. Similar values have been observed for GLVs. Ejoh et al. [25] reported $89.98 \mathrm{mg} / 100 \mathrm{~g}$ DW for C. maxima, $164.58 \mathrm{mg} / 100 \mathrm{DW}$ for $S$. macrocarpon and $87.24 \mathrm{mg} / 100 \mathrm{~g} \mathrm{DW}$ for $A$. hybridus. Oulai et al. [26] also reported similar values for $A$. hybridus.

Boiling of the vegetables significantly reduced the iron content in the vegetables with losses ranging from $12.42 \%$ in $S$. scrabrum to $65.43 \%$ in $S$. macrocarpon. The results are comparable to that of Tsado et al. [27] for $V$. amygdalina. For the vegetables cooked with tomatoes, the iron content is significantly lower than that of the boiled samples except for those of A. hybridus C. esculenta and T. occidentalis. A dilution effect is therefore expected in the recipes cooked with tomatoes because it contains relatively lower amounts of iron $(0.9 \mathrm{mg} / 100 \mathrm{~g} \mathrm{FW})$, when compared with the green leafy vegetables [28]. Similar results were also observed for the vegetables that were cooked with groundnut, except in $C$. esculenta and $C$. maxima, which recorded higher values. All vegetables that were cooked with melon seeds also had significantly lower iron levels except for $C$. esculenta, which recorded an increase. The dilution effect observed after cooking with peanuts and melon seeds were expected as these seeds contain relatively lower iron content than the raw GLVs [29]. Djuikwo et al. [11], demonstrated loweriron levels after cooking green leafy vegetables with peanuts. 
Table 3. Iron content in the raw, boiled and cooked green leafy vegetables (mg/100g DW).

\begin{tabular}{|c|c|c|c|c|c|c|}
\hline GLVs & Raw & Boiled & A & B & $\mathrm{C}$ & $\mathrm{D}$ \\
\hline A.hybridus & $81.96 \pm 0.36^{c}$ & $50.09 \pm 1.86^{\mathrm{b}}$ & $78.15 \pm 0.47^{c}$ & $35.38 \pm 6.11^{\mathrm{a}}$ & $31.70 \pm 3.97^{\mathrm{a}}$ & $77.29 \pm 4.46^{\mathrm{c}}$ \\
\hline C. esculenta & $45.90 \pm 1.73^{\mathrm{b}}$ & $32.47 \pm 3.04^{\mathrm{a} \star}$ & $46.09 \pm 4.26^{\mathrm{bc}}$ & $53.34 \pm 2.10^{c}$ & $46.47 \pm 0.46^{\mathrm{bc}}$ & $66.85 \pm 2.91^{\mathrm{d}}$ \\
\hline S.scrabrum & $96.14 \pm 6.46^{\mathrm{e}}$ & $84.20 \pm 2.54^{\mathrm{d}}$ & $63.13 \pm 1.85^{c}$ & $46.77 \pm 3.27^{\mathrm{b}}$ & $45.26 \pm 3.28^{\mathrm{b}}$ & $81.18 \pm 1.51^{\mathrm{a} \star *}$ \\
\hline V.amygdalina & $93.22 \pm 3.92^{\mathrm{d}}$ & $71.68 \pm 1.73^{\mathrm{c}}$ & $63.97 \pm 3.73 b^{c}$ & $59.75 \pm 6.65^{\mathrm{b}}$ & $35.71 \pm 4.03^{\mathrm{a}}$ & $128.28 \pm 4.48^{\mathrm{e}}$ \\
\hline C. maxima & $82.60 \pm 0.80^{\mathrm{e}}$ & $31.57 \pm 3.30^{c}$ & $27.10 \pm 1.92^{\mathrm{b}}$ & $42.59 \pm 1.79^{\mathrm{d}}$ & $12.10 \pm 0.57^{\mathrm{a}}$ & $42.20 \pm 0.35^{\mathrm{d}}$ \\
\hline T.occidentalis & $138.37 \pm 1.93^{\mathrm{d}}$ & $71.49 \pm 1.87^{\mathrm{c}}$ & $134.65 \pm 1.88^{\mathrm{d}}$ & $50.46 \pm 5.39^{\mathrm{b}}$ & $34.61 \pm 3.09^{\mathrm{a}}$ & $52.64 \pm 6.30^{\mathrm{b}}$ \\
\hline S.macrocarpon & $180.03 \pm 3.92^{\mathrm{e}}$ & $62.23 \pm 1.69^{c}$ & $52.66 \pm 2.52^{\mathrm{b}}$ & $46.05 \pm 3.22^{\mathrm{b}}$ & $31.51 \pm 1.51^{\mathrm{a}}$ & $80.50 \pm 4.43^{\mathrm{d}}$ \\
\hline
\end{tabular}

Values with different superscript in the same row are significantly different $(\mathrm{p}<0.05)$; ${ }^{\star}$ no tomato was added in the preparation of the sauce; ${ }^{\star *}$ the vegetable was cooked only with red palm oil and seasoning cube; A: with tomato; B: with pumpkin seeds; C: with peanut seeds; D: with soybean seeds

All the sauces cooked with soybean recorded significant higher iron content than in the boiled vegetables, with levels in $V$. amygdalina and $C$. esculenta being significantly higher than even the raw samples. This is as a result of high iron levels $(600 \mathrm{mg} / 100 \mathrm{~g})$ in the soybean [30].

\subsection{Influence of Cooking of Different Vegetables on the Anti-Nutrient Levels}

The antinutrient content of the raw and cooked green leafy vegetables are shown in Table 4. The total phenolics contents in the raw samples ranged from $0.65 \pm$ $0.02 \mathrm{~g} / 100 \mathrm{~g}$ DW in $C$. maxima to $1.95 \pm 0.32 \mathrm{~g} / 100 \mathrm{~g}$ DW in $V$. amygdalina on dry weight (DW) basis. Boiling GLVs resulted in significant reductions in the total phenolic content of the vegetables except in $C$. esculenta leaves. The least loss was observed in $C$. esculenta, which may be because this vegetable was not drained after boiling. Oulai et al. [26] recorded losses in total phenolics content after boiling green leafy vegetables for $15 \mathrm{~min}$. Higher losses recorded in $V$. amygdalina leaves can be explained by the physical crushing (Squeeze-washing), which certainly caused more destruction of the plant cell wall, and therefore enhancing the leaching of the compounds. These results indicate that the reduction in total phenolics observed as a result of boiling the vegetables could be attributed to the leaching effect.

Vegetables cooked with tomatoes had no change in the total phenolic content though in $S$. scrabrum there was an increase. Tomatoes contain relatively lower quantities of total phenolics (312.2 - 557.8 mg GAE/Kg fresh weight [31]. For $C$. maxima, only those cooked with peanut recorded an increase in total phenolics when compared with the boiled vegetables. The increase in total phenolics can be explained by the high content of total phenolic content in peanuts $(8.2 \mathrm{~g}$ GAE/100g DW) [32]. The lower values observed for other vegetables could be due to of leaching of the compounds from the peanuts during the soaking process as peanuts were soaked before use. Cooking the boiled vegetables with melon seeds ("egusi") resulted in the highest percentage reductions of total phenolics content when compared with the boiled respective vegetables. The 
Table 4. Antinutrient contents of the raw and cooked green leafy vegetables $(\mathrm{g} / 100 \mathrm{~g})$ DW.

\begin{tabular}{|c|c|c|c|c|c|}
\hline GLVs & Form & Phytates & Tannins & Oxalates & Phenolic C \\
\hline \multirow[t]{6}{*}{ A. hybridus } & Raw & $0.13 \pm 0.01^{\mathrm{a}}$ & $0.38 \pm 0.02^{\mathrm{d}}$ & $5.80 \pm 0.33^{\mathrm{e}}$ & $1.41 \pm 0.11^{\mathrm{c}}$ \\
\hline & Boiled & $0.07 \pm 0.01^{\mathrm{a}}$ & $0.21 \pm 0.00^{\mathrm{b}}$ & $4.67 \pm 0.18^{\mathrm{d}}$ & $0.40 \pm 0.07^{\mathrm{ab}}$ \\
\hline & A & $0.17 \pm 0.04^{\mathrm{ab}}$ & $0.26 \pm 0.01^{\mathrm{c}}$ & $4.76 \pm 0.17^{\mathrm{d}}$ & $0.46 \pm 0.04^{\mathrm{b}}$ \\
\hline & B & $0.28 \pm 0.06^{\mathrm{b}}$ & $0.12 \pm 0.01^{\mathrm{a}}$ & $2.78 \pm 0.17^{\mathrm{b}}$ & $0.41 \pm 0.04^{\mathrm{ab}}$ \\
\hline & $\mathrm{C}$ & $0.89 \pm 0.07^{\mathrm{c}}$ & $0.11 \pm 0.00^{\mathrm{a}}$ & $1.95 \pm 0.00^{\mathrm{a}}$ & $0.29 \pm 0.03^{\mathrm{a}}$ \\
\hline & $\mathrm{D}$ & $0.09 \pm 0.00^{\mathrm{a}}$ & $0.14 \pm 0.00^{\mathrm{a}}$ & $3.64 \pm 0.18^{c}$ & $0.41 \pm 0.02^{\mathrm{ab}}$ \\
\hline \multirow[t]{6}{*}{ C. esculenta } & Raw & $0.12 \pm 0.02^{\mathrm{b}}$ & $0.54 \pm 0.02^{c}$ & $4.51 \pm 0.00^{\mathrm{d}}$ & $1.09 \pm 0.11^{\mathrm{b}}$ \\
\hline & Boiled & $0.07 \pm 0.01^{\mathrm{ab}}$ & $0.49 \pm 0.01^{c}$ & $3.95 \pm 0.00^{c}$ & $0.98 \pm 0.05^{\mathrm{b}}$ \\
\hline & A & $\mathrm{ND}^{*}$ & $0.35 \pm 0.01^{\mathrm{b} *}$ & $4.67 \pm 0.00^{\mathrm{d} x}$ & $1.03 \pm 0.10^{\mathrm{b} *}$ \\
\hline & B & $0.27 \pm 0.02^{c}$ & $0.19 \pm 0.01^{\mathrm{a}}$ & $2.16 \pm 0.18^{\mathrm{a}}$ & $0.62 \pm 0.16^{\mathrm{a}}$ \\
\hline & $\mathrm{C}$ & $0.70 \pm 0.06^{\mathrm{d}}$ & $0.14 \pm 0.00^{\mathrm{a}}$ & $2.72 \pm 0.00^{\mathrm{b}}$ & $0.38 \pm 0.02^{\mathrm{a}}$ \\
\hline & $\mathrm{D}$ & $0.10 \pm 0.02^{\mathrm{b}}$ & $0.18 \pm 0.01^{\mathrm{a}}$ & $4.05 \pm 0.00^{c}$ & $0.61 \pm 0.06^{\mathrm{a}}$ \\
\hline \multirow[t]{6}{*}{ S. scrabrum } & Raw & $0.08 \pm 0.01^{\mathrm{a}}$ & $0.49 \pm 0.02^{c}$ & $11.92 \pm 0.00^{\mathrm{d}}$ & $1.92 \pm 0.11^{\mathrm{d}}$ \\
\hline & Boiled & $0.05 \pm 0.00^{\mathrm{a}}$ & $0.24 \pm 0.02^{\mathrm{b}}$ & $2.42 \pm 0.18^{\mathrm{a}}$ & $0.33 \pm 0.05^{\mathrm{ab}}$ \\
\hline & $\mathrm{A}$ & ND & $0.29 \pm 0.02^{\mathrm{b}}$ & $2.32 \pm 0.17^{\mathrm{a}}$ & $0.91 \pm 0.08^{\mathrm{c}}$ \\
\hline & B & $0.08 \pm 0.00^{\mathrm{a}}$ & $0.12 \pm 0.00^{\mathrm{a}}$ & $6.16 \pm 0.00^{c}$ & $0.48 \pm 0.04^{\mathrm{b}}$ \\
\hline & $\mathrm{C}$ & $0.65 \pm 0.07^{c}$ & $0.10 \pm 0.00^{\mathrm{a}}$ & $4.60 \pm 0.18^{\mathrm{b}}$ & $0.25 \pm 0.02^{\mathrm{a}}$ \\
\hline & $\mathrm{D}$ & $0.02 \pm 0.00^{a \star \star}$ & $0.45 \pm 0.01^{c * *}$ & $2.26 \pm 0.00^{\mathrm{a} \star \star}$ & $0.98 \pm 0.10^{c * *}$ \\
\hline \multirow[t]{6}{*}{$V$. amygdalina } & Raw & $0.32 \pm 0.06^{\mathrm{b}}$ & $0.36 \pm 0.01^{\mathrm{c}}$ & $7.32 \pm 0.55^{\mathrm{e}}$ & $1.95 \pm 0.32^{\mathrm{b}}$ \\
\hline & Boiled & ND & $0.09 \pm 0.01^{\mathrm{a}}$ & $1.29 \pm 0.00^{\mathrm{a}}$ & $0.17 \pm 0.02^{\mathrm{a}}$ \\
\hline & A & $0.11 \pm 0.00^{\mathrm{ab}}$ & $0.17 \pm 0.01^{\mathrm{b}}$ & $5.20 \pm 0.00^{\mathrm{d}}$ & $0.44 \pm 0.06^{\mathrm{a}}$ \\
\hline & B & $0.36 \pm 0.03^{b}$ & $0.05 \pm 0.00^{\mathrm{a}}$ & $4.89 \pm 0.18^{\mathrm{d}}$ & $0.50 \pm 0.13^{\mathrm{a}}$ \\
\hline & C & $1.50 \pm 0.10^{c}$ & $0.06 \pm 0.01^{\mathrm{a}}$ & $2.42 \pm 0.00^{\mathrm{b}}$ & $0.18 \pm 0.01^{\mathrm{a}}$ \\
\hline & $\mathrm{D}$ & $0.33 \pm 0.08^{\mathrm{b}}$ & $0.10 \pm 0.01^{\mathrm{a}}$ & $3.74 \pm 0.18^{c}$ & $0.51 \pm 0.13^{\mathrm{a}}$ \\
\hline \multirow[t]{6}{*}{ C. maxima } & Raw & $0.15 \pm 0.03^{\mathrm{a}}$ & $0.18 \pm 0.01^{\mathrm{b}}$ & $5.09 \pm 0.00^{\mathrm{e}}$ & $0.65 \pm 0.02^{\mathrm{c}}$ \\
\hline & Boiled & $0.15 \pm 0.02^{\mathrm{a}}$ & $0.09 \pm 0.00^{\mathrm{ab}}$ & $1.70 \pm 0.00^{\mathrm{b}}$ & $0.13 \pm 0.01^{\mathrm{a}}$ \\
\hline & A & ND & $0.08 \pm 0.00^{\mathrm{a}}$ & $3.18 \pm 0.00^{c}$ & $0.23 \pm 0.01^{\mathrm{ab}}$ \\
\hline & B & $0.16 \pm 0.06^{\mathrm{a}}$ & $0.17 \pm 0.00^{\mathrm{b}}$ & $1.22 \pm 0.00^{\mathrm{a}}$ & $0.37 \pm 0.04^{\mathrm{b}}$ \\
\hline & $\mathrm{C}$ & $0.64 \pm 0.05^{c}$ & $0.15 \pm 0.00^{\mathrm{ab}}$ & $3.67 \pm 0.00^{\mathrm{d}}$ & $0.20 \pm 0.03^{\mathrm{a}}$ \\
\hline & $\mathrm{D}$ & $0.29 \pm 0.01^{\mathrm{cb}}$ & $0.15 \pm 0.00^{\mathrm{ab}}$ & $6.46 \pm 0.00^{f}$ & $0.37 \pm 0.05^{\mathrm{b}}$ \\
\hline \multirow[t]{6}{*}{ T. occidentalis } & Raw & $0.08 \pm 0.01^{\mathrm{a}}$ & $0.18 \pm 0.02^{c}$ & $6.33 \pm 0.17^{\mathrm{d}}$ & $1.34 \pm 0.05^{\mathrm{d}}$ \\
\hline & Boiled & ND & $0.10 \pm 0.01^{\mathrm{ab}}$ & $0.75 \pm 0.00^{\mathrm{a}}$ & $0.49 \pm 0.09^{\mathrm{ab}}$ \\
\hline & A & ND & $0.14 \pm 0.01^{\mathrm{bc}}$ & $2.45 \pm 0.00^{\mathrm{b}}$ & $0.52 \pm 0.05^{\mathrm{b}}$ \\
\hline & B & $0.20 \pm 0.06^{\mathrm{b}}$ & $0.06 \pm 0.01^{\mathrm{a}}$ & $3.70 \pm 0.00^{c}$ & $0.45 \pm 0.04^{\mathrm{ab}}$ \\
\hline & $\mathrm{C}$ & $1.21 \pm 0.01^{c}$ & $0.12 \pm 0.00^{\mathrm{b}}$ & $2.42 \pm 0.00^{\mathrm{b}}$ & $0.65 \pm 0.02^{\mathrm{a}}$ \\
\hline & $\mathrm{D}$ & $0.26 \pm 0.06^{\mathrm{b}}$ & $0.09 \pm 0.01^{\mathrm{ab}}$ & $3.74 \pm 0.00^{c}$ & $0.72 \pm 0.06^{c}$ \\
\hline \multirow[t]{6}{*}{ S. macrocarpon } & Raw & $0.13 \pm 0.01^{\mathrm{b}}$ & $0.26 \pm 0.03^{c}$ & $2.49 \pm 0.18^{\mathrm{b}}$ & $1.90 \pm 0.13^{\mathrm{b}}$ \\
\hline & Boiled & $0.08 \pm 0.01^{\mathrm{ab}}$ & $0.15 \pm 0.01^{\mathrm{a}}$ & $1.72 \pm 0.00^{\mathrm{a}}$ & $0.44 \pm 0.02^{\mathrm{a}}$ \\
\hline & A & ND & $0.24 \pm 0.01^{\mathrm{bc}}$ & $2.68 \pm 0.18^{\mathrm{b}}$ & $0.44 \pm 0.02^{\mathrm{a}}$ \\
\hline & B & $0.40 \pm 0.03^{\mathrm{d}}$ & $0.07 \pm 0.00^{\mathrm{a}}$ & $3.24 \pm 0.00^{c}$ & $0.41 \pm 0.01^{\mathrm{a}}$ \\
\hline & $\mathrm{C}$ & $1.63 \pm 0.07^{\mathrm{e}}$ & $0.08 \pm 0.02^{\mathrm{a}}$ & $1.74 \pm 0.00^{\mathrm{a}}$ & $0.34 \pm 0.07^{\mathrm{a}}$ \\
\hline & $\mathrm{D}$ & $0.28 \pm 0.02^{c}$ & $0.16 \pm 0.02^{\mathrm{ab}}$ & $2.35 \pm 0.17^{\mathrm{b}}$ & $0.48 \pm 0.03^{\mathrm{a}}$ \\
\hline
\end{tabular}

Values with different superscript in the same column are significantly different $(\mathrm{p}<0.05) .{ }^{*}$ indicates that no tomato was added in the preparation of the meal ${ }^{* *}$ indicates that the vegetable was cooked only with red palm oil and maggi seasoning cube, $\mathrm{ND}=$ non-detectable. 
findings observed can be attributed to the relatively lower total phenolic levels of melon seeds (2.49 g GAE/100g DW) [33]. In the vegetables cooked with soybean, the total phenolic content was not significantly different except for sauces cooked with $C$. maxima and $T$. occidentalis which recorded significant higher values than the boiled samples. Soybean can contain as high as $3.6 \mathrm{~g} / 100 \mathrm{~g}$ total phenolics [34].

The tannin levels in the raw samples ranged from $0.18 \pm 0.01 \mathrm{~g} / 100 \mathrm{~g}$ DW in $C$. maxima to $0.54 \pm 0.02 \mathrm{~g} / 100 \mathrm{~g} \mathrm{DW}$ in $C$. esculenta leaves. Boiling the raw GLVs resulted in a significant reduction in tannin levels except for $C$. esculenta. Cooking the boiled vegetables with tomatoes significantly increased their tannin levels except in C. maxima and S. scrabum where levels were not affected by the addition of tomatoes. The increase in the tannin levels can be explained by the high tannins content in tomatoes $(3.5 \mathrm{mg} / \mathrm{g} \mathrm{DW})$ as reported by Shen et al. [35]. Cooking the boiled vegetables with peanuts did not have an impact on the tannin content of the boiled vegetables except for $A$. hybridus, $C$. esculenta and $S$. scrabrum where significant reductions in the tannin levels were observed. One of the reasons for the reduction may be related to the tannin content of groundnut (1.6\%) [36] as well as the effect of soaking of the peanuts. The vegetables cooked with melon seeds, A. hybridus, C. esculenta and S. scrabrum had significantly lower values than the boiled samples, while the others remained the same. The trend can be explained by the tannin levels in "egusi" melon seeds ( $49.67 \pm$ $3.91 \mathrm{mg} / 100 \mathrm{~g}$ ) which are lower than the tannin levels in the boiled vegetables [37]. The sauces cooked with soybean had varied tannin levels with those of $A$. hybridus and C. esculenta recording lower levels than the boiled samples while the others remained statistically the same. Soybeans contain relatively lower tannins levels of $(25.23 \mathrm{mg} / 100 \mathrm{~g})$ [38] compared to the green leafy vegetables. Sharma et al. [34], reported higher levels. These variations in the tannin levels could also account for its variations when cooked with the boiled vegetables.

The oxalate levels in the raw GLVs ranged between $2.49 \pm 0.18 \mathrm{~g} / 100 \mathrm{~g}$ DW in S. macrocarpon and $11.92 \pm 0.00 \mathrm{~g} / 100 \mathrm{~g}$ DW in $S$. scrabrum. Boiling caused a significant decrease in oxalate levels in all the samples with percentage decrease ranging between $12.38 \%$ in C. esculenta and $88.11 \%$ in $T$. occidentalis. The losses observed show that leaching of oxalates is more responsible for reduction in the oxalate levels than is the effect of heat as can be seen with minimal reduction in C. esculenta. Akhtar et al. [39] showed that the least oxalate loss observed in the $C$. esculenta leaves was because, the water used to boil leaves was retained and therefore the leached out oxalates remained with the boiled vegetable. Furthermore, $C$. esculenta leaves had the least lost in oxalate levels despite the fact that its boiling time $(45 \mathrm{~min}$ ) was about three times more than that of the other vegetables. Paul et al. [40] and Judprasong et al. [41] showed similar results with up to $23 \%-59 \%$ loses after blanching and up to $21 \%-76 \%$ loses in the oxalate content of green leafy vegetables after blanching for $10 \mathrm{~min}$ in boiled water respectively. The addition of tomatoes to the boiled vegetables caused an increase in their oxalate levels compared to the boiled samples except for the vegetable 
prepared from A. hybridus and S. scrabrum whose oxalate levels remained unchanged. Judprasong et al. [41] reported $11 \mathrm{mg} / 100 \mathrm{~g}$ of oxalates in tomatoes. Cooking the boiled vegetables with groundnuts led to an increase in oxalate levels except in A. hybridus, C. esculenta and C. maxima. Boiled vegetables cooked with melon seeds also resulted in an increase in their oxalate levels except in $A$. hybridus, $C$. esculenta and $S$. macrocarpon. Cooking the boiled vegetables with soybean also increased the oxalate levels except in A. hybridus and C. esculenta. Most of the cooked vegetables recorded an increase in oxalate content compared with the boiled vegetables. The increases observed are likely from other minor ingredients added given that the added seeds contain relatively lower levels of oxalates compared to the boiled vegetables. Furthermore, Haron and Raob [42], showed that significant oxalate loses can occur after soaking in water. Cooking the boiled vegetables with tomato, peanuts, melon seeds and soybean all led to an increase in oxalate content of many of the samples even though literature reveals that their oxalate contents are lower than that of the raw vegetables. However, the added ingredients used in cooking process could account for the varying results observed [43].

The phytate levels were determined in the raw, boiled and cooked green leafy vegetables under study. The phytate levels in the raw GLVs ranged between 0.08 $\pm 0.01 \mathrm{~g} / 100 \mathrm{~g}$ DW in $S$. scrabrum and $0.32 \pm 0.06 \mathrm{~g} / 100 \mathrm{~g}$ DW in $V$. amygdalina. Boiling resulted in lossesof phytates in the green leafy vegetables. These results corroborate with earlier studies [26]. The findings of this study show that the loss of phytate is not only related to its leaching in water [44], but it is also due to its heat lability as seen with C. esculenta ( $40.36 \%$ loss) after boiling for $45 \mathrm{~min}$.Further cooking of the boiled vegetables with tomatoes showed levels that were not significantly different from those of the boiled vegetables. This was most probably because of the quantity of tomatoes used which did not contribute significant quantities of phytate and the cooking method could also have led to losses of phytate. Cooking the boiled vegetables with the added seeds all led to increased levels of phytates in the vegetables. The vegetables cooked with "egusi" melon seeds recorded the highest phytate levels ranging from 0.64 $\mathrm{g} / 100 \mathrm{~g}$ in C. maxima to $1.63 \mathrm{~g} / 100 \mathrm{~g}$ in $S$. marcrocarpon. The significant increase in the phytate levels can be accounted for by the high phytate content of the added seeds [34] [45] [46].

\subsection{Influence of Processing of Different Sauces on the Vitamin C Levels of GLVs}

The vitamin C levels in the raw GLVs ranged between $89.60 \pm 6.34 \mathrm{mg} / 100 \mathrm{~g}$ in $V$. amygdalina to $157.07 \pm 5.55 \mathrm{mg} / 100 \mathrm{~g}$ in $S$. macrocarpon DW (Table 5). Boiling the vegetables led to significant reduction in the levels of vitamin $\mathrm{C}(\mathrm{P}<$ 0.05). These values confirm the results obtained by Oulai et al., [26] and Babalola et al. [47]. Most reduction in the vitamin C level in the GLVs can be accounted for by its leaching into the boiling water which is later on discarded. Cooking with tomatoes increases the vitamin $\mathrm{C}$ levels in the cooked vegetables compared 
Table 5. Vitamin C content of raw and cooked green leafy vegetables (mg/100g Dry weight).

\begin{tabular}{ccccccc}
\hline $\begin{array}{c}\text { Green leafy } \\
\text { vegetable/treatments }\end{array}$ & Raw & Boiled & $\begin{array}{c}\text { Sauce cooked } \\
\text { with tomato }\end{array}$ & $\begin{array}{c}\text { Sauce cooked with } \\
\text { peanut seeds }\end{array}$ & $\begin{array}{c}\text { Sauce cooked with } \\
\text { Melon seeds }\end{array}$ & $\begin{array}{c}\text { Sauce cooked with } \\
\text { soybean seeds }\end{array}$ \\
\hline A. hybridus & $129.50 \pm 3.10^{\mathrm{c}}$ & $70.95 \pm 6.27^{\mathrm{b}}$ & $86.55 \pm 6.12^{\mathrm{b}}$ & $43.26 \pm 6.12^{\mathrm{a}}$ & $43.62 \pm 6.17^{\mathrm{a}}$ & $44.17 \pm 6.25^{\mathrm{a}}$ \\
C. esculenta & $108.20 \pm 6.38^{\mathrm{c}}$ & $66.21 \pm 6.69^{\mathrm{b}}$ & $70.16 \pm 8.27^{\mathrm{b} *}$ & $35.71 \pm 6.31^{\mathrm{a}}$ & $40.06 \pm 0.00^{\mathrm{a}}$ & $49.94 \pm 3.36^{\mathrm{ab}}$ \\
S. scrabrum & $145.04 \pm 6.41^{\mathrm{c}}$ & $80.60 \pm 8.14^{\mathrm{b}}$ & $86.33 \pm 6.10^{\mathrm{b}}$ & $26.46 \pm 3.12^{\mathrm{a}}$ & $44.17 \pm 7.81^{\mathrm{a}}$ & $74.09 \pm 3.88^{\mathrm{b} * *}$ \\
V. amygdalina & $89.60 \pm 6.34^{\mathrm{b}}$ & $26.87 \pm 6.33^{\mathrm{a}}$ & $71.74 \pm 6.34^{\mathrm{b}}$ & $17.38 \pm 6.14^{\mathrm{a}}$ & $8.74 \pm 6.18^{\mathrm{a}}$ & $9.08 \pm 6.42^{\mathrm{a}}$ \\
C. maxima & $136.07 \pm 6.41^{\mathrm{c}}$ & $87.58 \pm 6.19^{\mathrm{b}}$ & $127.59 \pm 6.01^{\mathrm{c}}$ & $31.44 \pm 2.96^{\mathrm{a}}$ & $33.92 \pm 6.00^{\mathrm{a}}$ & $43.46 \pm 6.15^{\mathrm{b}}$ \\
T. occidentalis & $105.83 \pm 6.24^{\mathrm{c}}$ & $52.44 \pm 6.18^{\mathrm{b}}$ & $113.21 \pm 6.16^{\mathrm{c}}$ & $17.20 \pm 6.08$ & $17.02 \pm 6.02^{\mathrm{a}}$ & $8.68 \pm 6.14^{\mathrm{a}}$ \\
S. macrocarpon & $157.07 \pm 5.55^{\mathrm{c}}$ & $91.44 \pm 8.08^{\mathrm{b}}$ & $199.96 \pm 3.98$ & $26.21 \pm 6.18^{\mathrm{a}}$ & $29.81 \pm 3.83^{\mathrm{a}}$ & $44.33 \pm 6.27^{\mathrm{a}}$ \\
\hline
\end{tabular}

Values with different superscript in the same row are significantly different $(\mathrm{p}<0.05) .{ }^{*}$ indicates that no tomato was added in the preparation of the sauce; $* *$ indicates that the vegetable was cooked only with red palm oil and maggi seasoning cube.

to the boiled vegetables except in vegetable cooked with A. hybridus and S. scrabrum which remained unchanged. The increase in vitamin $C$ levels can be accounted for by addition of high vitamin $\mathrm{C}$ tomatoes to the vegetable during preparation [48]. The addition of the boiled vegetables to groundnut, "egusi" and soybean, resulted in the highest reduction in vitamin C. This reduction is due to dilution of the vitamin $\mathrm{C}$ by the added paste due to their very low vitamin C content [49]. Vitamin C in iron absorption has been explained by its ability to prevent the formation of insoluble and unabsorbable iron compounds and to maintain iron in its reduced form (ferrous) which is absorbed from the intestine, hence improving on the bioavailability of iron [50]. Vegetables cooked with tomatoes provide vitamin $\mathrm{C}$ at levels that contribute significantly in meeting the daily requirements of the population. It has been shown that meals with high vitamin C levels are able to counteract the effect of anti-nutrients such as tannin and phytate [51].

\subsection{Influence of Cooking of the Different Vegetables on Their Iron Bioavailability}

The bioavailability of iron in the vegetables were determined in the raw, boiled and four cooked green leafy vegetables and the results are given in Table 6. The bioavailability of iron in the raw GLVs ranged between $1.90 \% \pm 0.36 \%$ in $S$. macrocarpon and $20.61 \% \pm 0.53 \%$ in S. scrabrum. Gupta et al. [5] obtained similar results. Boiling of the vegetables caused a significant increase in percent bioavailable iron for the vegetables except in $S$. scrabrum and C. maxima which had lower values. Djuikwo et al. [11] recorded lower values for bioavailability of boiled vegetables.

All the vegetables cooked with tomatoes had a significantly higher bioavailable iron than in the raw and boiled samples except for the boiled A. hybridus that remained unchanged. The increase in bioavailability can be accounted for by the increase in vitamin $\mathrm{C}$ brought about by the added tomato [48]. This enhancement in the bioavailability of iron by the addition of tomato is expected because of the enhancing effect of vitamin $\mathrm{C}$ on iron absorption. Furthermore, it has 
Table 6. Iron bioavailability in the GLV samples (\%).

\begin{tabular}{|c|c|c|c|c|c|c|}
\hline $\begin{array}{c}\text { Green leafy } \\
\text { vegetable/treatments }\end{array}$ & Raw & Boiled & $\begin{array}{l}\text { Sauce cooked } \\
\text { with tomato }\end{array}$ & $\begin{array}{l}\text { Sauce cooked with } \\
\text { peanut seeds }\end{array}$ & $\begin{array}{l}\text { Sauce cooked with } \\
\text { Melon seeds }\end{array}$ & $\begin{array}{l}\text { Sauce cooked with } \\
\text { soybean seeds }\end{array}$ \\
\hline A. hybridus & $16.44 \pm 3.42^{\mathrm{a}}$ & $27.77 \pm 6.08^{c}$ & $28.09 \pm 0.71^{\mathrm{c}}$ & $26.15 \pm 0.29^{b c}$ & $13.28 \pm 2.04^{\mathrm{a}}$ & $19.48 \pm 0.94^{\mathrm{ab}}$ \\
\hline C. esculenta & $12.18 \pm 1.15^{\mathrm{bc}}$ & $15.78 \pm 2.47^{\mathrm{c}}$ & $9.29 \pm 0.84^{\mathrm{ab} \star}$ & $6.96 \pm 0.91^{\mathrm{a}}$ & $7.51 \pm 3.26^{\mathrm{ab}}$ & $8.55 \pm 0.28^{\mathrm{ab}}$ \\
\hline S. scrabrum & $20.61 \pm 0.53^{\mathrm{de}}$ & $13.28 \pm 0.38^{\mathrm{bc}}$ & $16.74 \pm 1.84^{\mathrm{cd}}$ & $24.52 \pm 0.77^{\mathrm{e}}$ & $7.03 \pm 1.20^{\mathrm{a}}$ & $9.06 \pm 3.34^{\mathrm{ab} * *}$ \\
\hline V. amygdalina & $12.91 \pm 0.69^{c}$ & $13.21 \pm 0.86^{c}$ & $18.94 \pm 1.75^{\mathrm{d}}$ & $1.95 \pm 0.74^{\mathrm{a}}$ & $5.98 \pm 1.33^{\mathrm{b}}$ & $7.38 \pm 0.14^{\mathrm{b}}$ \\
\hline C. maxima & $14.69 \pm 0.80^{c}$ & $8.47 \pm 0.87^{\mathrm{b}}$ & $43.20 \pm 1.31^{\mathrm{d}}$ & $3.32 \pm 0.00^{\mathrm{ab}}$ & $2.49 \pm 4.69^{\mathrm{a}}$ & $3.33 \pm 0.68^{\mathrm{ab}}$ \\
\hline T. occidentalis & $7.76 \pm 0.76^{\mathrm{b}}$ & $12.51 \pm 0.32^{\mathrm{c}}$ & $17.40 \pm 0.41^{\mathrm{d}}$ & $7.29 \pm 0.82^{b}$ & $4.69 \pm 1.75^{\mathrm{a}}$ & $22.92 \pm 0.52^{\mathrm{e}}$ \\
\hline S. macrocarpon & $1.90 \pm 0.36^{\mathrm{a}}$ & $12.04 \pm 1.64^{\mathrm{b}}$ & $31.61 \pm 1.60^{\mathrm{d}}$ & $8.07 \pm 3.10^{\mathrm{b}}$ & $2.92 \pm 0.55^{\mathrm{a}}$ & $25.46 \pm 0.37^{c}$ \\
\hline
\end{tabular}

Values with different superscript letter in the same row are significantly different $(\mathrm{p}<0.05) .{ }^{*}$ indicates that no tomato was added in the preparation of the sauce, ${ }^{* *}$ indicates that the vegetable was cooked only with red palm oil and maggi seasoning cube.

been shown that meals with high vitamin C levels are able to counteract the effect of anti-nutrients such as tannin and phytate [50], hence improvement in iron bioavailability. Singh et al., [52] reported an increase in iron bioavailability with the addition of tomatoes to leguminous seeds.

All the vegetables cooked with peanuts and melon seeds had significantly lower bioavailable iron than in the boiled samples. In vegetables cooked with soybean, the bioavailable iron was significantly lower than in the boiled samples except for those cooked of $T$. occidentalis and $S$. macrocarpon whose bioavailable iron percentages are higher than in the raw and boiled vegetable. The lower bioavailability is expected as these vegetables contain lower quantities of iron absorption enhancer (vitamin C) and an increased amount of phytate. However, the effect of ascorbic acid and phytate are not the only factors to be considered in bioavailability of iron.

\subsection{Correlation between Anti-Nutrient Levels, Vitamin C Content and Iron Bioavailability}

The bioavailability of iron was negatively related to the phytate and positively related to the vitamin $\mathrm{C}$ content of the green leafy vegetables and the vegetables prepared from them had correlation coefficients of $\mathrm{r}=-0.43, \mathrm{P}=0.0046$ and $\mathrm{r}=$ $0.44, \mathrm{P}=0.003$ respectively. Phenolic compounds had no significant impact on the percent bioavailability $(\mathrm{P}=0.94)$ and corroborate the studies by Brune et al. [53] suggesting that condensed tannins do not necessarily interfere with iron absorption. There was also no significant correlation between the oxalic acid levels in the vegetable samples and iron bioavailability $(\mathrm{P}=0.36)$ as had been shown earlier [54].

\section{Conclusions}

Seven principal vegetables are consumed in Bamenda in the North West region of Cameroon. These are A. hybridus, C. esculenta, S. scrabrum, V. amygdalina, 
C. maxima, T. occidentalis and S. macrocarpon. Apart for S. scrabrum, which is prepared using only three principal ingredients (tomatoes, melon seeds and peanuts), all the other leafy vegetables are prepared using 4 major ingredients (tomatoes, melon seeds, peanuts and soybeans). Onion and unrefined palm oil are also used in the preparations as minor ingredients.

Preparation and cooking of the GLVs with the addition of the principal ingredients all led to a decrease in the iron content except for the vegetables cooked with soybean as principal ingredient. Total phenolic contents were reduced in all the four cooked vegetables. Most of the vegetables were lower in tannin content compared to the raw and boiled GLV. The oxalate content of most of the vegetables had higher values when compared to the boiled vegetables; and for phytate levels, the addition of egusi melon seeds led to an increase in phytate levels. All vegetables cooked without tomatoes had lower vitamin C levels than those containing tomatoes.

The addition of tomatoes in the preparation of GLV improves the bioavailability of iron than any other major ingredient. Only phytate and vitamin C correlate with iron bioavailability; with phytates negatively correlating with iron bioavailability while vitamin $\mathrm{C}$ positively correlating with iron bioavailability. Therefore, addition of tomatoes to GLV can be useful in food-based strategies to fight iron deficiencies.

\section{Conflicts of Interest}

The authors declare no conflicts of interest regarding the publication of this paper.

\section{References}

[1] Bailey, R.L., West. J.K.P. and Black, R.E. (2015) The Epidemiology of Global Micronutrient Deficiencies. Food and Nutrition Board, 30, 254-259.

[2] Al-Sayes, F., Gari, M., Qusti, S., Bagatian, N. and Abuzenadah, A. (2011) Prevalence of Iron Deficiency and Iron Deficiency Anemia among Females at University Stage. Journal of Medical Laboratory and Diagnosis, 2, 5-11.

[3] Failla, M.L. (2003) Trace Elements and Host Defense: Recent Advances and Continuing Challenges. The Journal of Nutrition, 133, 1443S-1447S.

https://doi.org/10.1093/jn/133.5.1443S

[4] WHO (2000) Report on the World Nutrition Situation. Geneva, Switzerland. http://www.unsystem.org/scn/archives/rwns04/index.htm

[5] Gupta, A. and Yadav, N. (2016) Evaluation of Nutritional and Anti-Nutritional Activity of Indigenous and Underutilized Green Leafy Vegetables of North India. International Journal of Food and Nutritional Science, 5, 88-95.

[6] Agbaire, P.O. and Emoyan, O.O. (2012) Nutritional and Antinutritional Levels of Some Local Vegetables from Delta State, Nigeria. African Journal of Food Science, 6, 8-11.

[7] Hurrell, R. and Egli, I. (2010) Iron Bioavailability and Dietary Reference Values. The American Journal of Clinical Nutrition, 91, 1461S-1467S.

https://doi.org/10.3945/ajcn.2010.28674F 
[8] Ejoh, R.A., Djuikwo, V.N., Gouado, I. and Mbofung, C.M. (2007) Nutritional Components of Some Non-Conventional Leafy Vegetables Consumed in Cameroon. Pakistan Journal of Nutrition, 6, 712-717.

https://doi.org/10.3923/pjn.2007.712.717

[9] Elie, R., Fokou, E., Beaucher, E., Piot, M. and Gaucheron, F. (2016) Nutrient Content of Some Cameroonian Traditional Dishes and Their Potential Contribution to Dietary Reference Intakes. Food Science \& Nutrition, 4, 696-705. https://doi.org/10.1002/fsn3.334

[10] Djuikwo, V.N., Ejoh, R.A. and Mbofung, C.A. (2017) Mineral Profile and the Effect of Processing of Some Leafy Vegetables Indigenous to Cameroon. African Journal of Food, Agriculture, Nutrition and Development, 17, 12362-12376. https://doi.org/10.18697/ajfand.79.15410

[11] Djuikwo, N.R.V., Ejoh, A.R., Mbofung, C.M., Tanya, N.A. and Gouado, I. (2015) In Vitro Bioavailability of Iron from Some Non-Conventional Leafy Vegetables Consumed in Cameroon. International Journal of Current Advanced Research, 4, 278-284.

[12] Ngaha, D., Fombang, E. and Ejoh, R. (2014) Dietary Intake of Vitamin A and Macronutrients among Pregnant Women in Ngaoundere Town, Adamawa Region, Cameroon. Food and Nutrition Sciences, 5, 2071-2080. https://doi.org/10.4236/fns.2014.521219

[13] Ngaha, D.W., Fombang, E.N. and Ejoh, A.R. (2016) Evaluation of Vitamin A Deficiency Risks among Lactating Mothers Unngaoundere, Adamawa Region of Cameroon. International Journal of Food and Nutritional Science, 5, 86-95.

[14] Sop, K., Gouado, I., Mofor, C. and Smriga, M. (2008) Mineral Content of Some Cameroonian Household Foods Eaten in Douala. African Journal of Biotechnology, 7, 3085-3091.

[15] Frison, E.A., Smith, I.F., Johns, T., Cherfas, J. and Eyzaguirre, P.B. (2006) Agricultural Biodiversity, Nutrition, and Health: Making a Difference to Hunger and $\mathrm{Nu}-$ trition in the Developing World. Food and Nutrition Bulletin, 27, 167-179. https://doi.org/10.1177/156482650602700208

[16] Chagomoka, T., Kamga, R., Tenkouano, A. and Mecozzi, M. (2014) Traditional Vegetables: Recipes from Cameroon. AVRDC-The World Vegetable Center, Shanhua, Taiwan, $55 \mathrm{p}$.

[17] Kawashima, L.M., Soares, L. and Valente, M. (2003) Mineral Profile of Raw and Cooked Leafy Vegetables Consumed in Southern Brazil. Journal of Food Composition and Analysis, 16, 605-611. https://doi.org/10.1016/S0889-1575(03)00057-7

[18] Rao, B.S.N. and Prabhavathi, T. (1983) Contaminant Iron in Foods and Its Bioavailability Predicted by in Vitro Method. Indian Journal of Medical Research, 74, 37-41.

[19] AOAC (1965) Official Methods of Analysis of the Association of Official Agricultural Chemists. AOAC, Washington DC.

[20] Haug, W. and Lantzschb, H.J. (1983) Sensitive Method for the Rapid Determination of Phytate in Cereal and Cereal Products. Journal of the Science of Food and Agriculture, 34, 1423-1426. https://doi.org/10.1002/jsfa.2740341217

[21] AOAC (1990) Association of Official Analytical Chemists Official Methods of Analysis. 13th Edition, AOAC, Washington DC.

[22] Dewanto, V., Wu, X., Adom, K.K. and Liu, R.H. (2002) Thermal Processing Enhances the Nutritional Value of Tomatoes by Increasing Total Antioxidant Activity. Journal of Agricultural and Food Chemistry, 50, 3010-3014. 
https://doi.org/10.1021/jf0115589

[23] Koziol, M.J. (1990) Afrosimetric Estimation of Threshold Saponin Concentration for Bitterness in Quinoa. Journal of the Science of Food and Agriculture, 54, 211-220. https://doi.org/10.1002/jsfa.2740540206

[24] Bainbridge, Z., Tomlins, K., Willings, K. and Westby, A. (1996) Methods for Assessing Quality Characteristics of Non Grain Starch Staple (Part 4 Advanced Methods). National Resources Institute, University of Greenwich, London, 143-479.

[25] Ejoh, A.R., Djuikwo, N.R.V. and Mbofung, C.M. (2017) Mineral Profile and the Effect of Processing of Some Leafy Vegetables Indigenous to Cameroon. The African Journal of Food, Agriculture, Nutrition and Development, 17, 12362-12376. https://doi.org/10.18697/ajfand.79.15410

[26] Oulai, P., Zoue, L., Megnanou, R., Doue, R., and Niamke, S. (2014) Proximate Composition and Nutritive Value of Leafy Vegetables Consumed in Northern Cote D'Ivoire. European Scientific Journal, 10, 212-227.

[27] Tsado, A.N., Lawal, B., Santali, E.S., Shaba, A.M., Chirama, D.N., Balarabe, M.M., Jiya, A.G. and Alkali, H.A. (2015) Effect of Different Processing Methods on Nutritional Quality of Bitterleaf (Vernonia amygdalina). Journal of Pharmacy, 5, 8-14.

[28] Paul, D.K. and Shaba, R.K. (2004) Nutrients Vitamins and Mineral Content in Common Citrus Fruits in the Northern Region of Bangladesh. Pakistan Journal of Biological Sciences, 7, 238-242. https://doi.org/10.3923/pjbs.2004.238.242

[29] Abdualrahman, M.A.Y. (2013) Chemical, in Vitro Protein Digestibility, Minerals and Amino Acids Composition of Edible Peanut Seeds (Arachis hypogaea L.). Science International, 1, 199-202. https://doi.org/10.5567/sciintl.2013.199.202

[30] Mahesh, S., Pavithra, G.J., Parvathi, M.S., Reddy, R. and Shankar, A.G. (2015) Effect of Processing on Phytic Acid Content and Nutrient Availability in Food Grains. International Journal of Agricultural Sciences, 5, 771-777.

[31] Maršić, N.K., Gašperlin, L., Abram, V., Budič, M. and Vidrih, R. (2011) Quality Parameters and Total Phenolic Content in Tomato Fruits Regarding Cultivar and Microclimatic Conditions. Turkish Journal of Agriculture and Forestry, 35, 185-194.

[32] Khaopha, S., Senawong, T., Jogloy, S. and Patanothai, A. (2012) Comparison of Total Phenolic Content and Composition of Individual Phenolic Acids in Testae and Testa-Removed Kernels of 15 Valencia-Type Peanut (Arachis hypoglea L.) Genotypes. African Journal of Biotechnology, 11, 15923-15930.

https://doi.org/10.5897/AJB12.1389

[33] Rathanavel, C. and Arasu, P.T. (2014) Antioxidant Activity, Phenol and Flavonoid Contents of Some Selected Indian Medicinal Plants. International Journal of Current Microbiology and Applied Sciences, 3, 830-838.

[34] Sharma, S., Goyal, R. and Barwal, S. (2013) Domestic Processing Effects on Physiochemical, Nutritional and Anti-Nutritional Attributes in Soybeans (Glycine Max L. Merill). International Food Research Journal, 20, 3203-3209.

[35] Shen, Y.C., Chen, S.L., Zhuang, S.R. and Wang, C.K. (2008) Contribution of Tomato Phenolics to Suppression of COX-2 Expression in KB Cells. Journal of Food Sciences, 73, 1-10. https://doi.org/10.1111/j.1750-3841.2007.00594.x

[36] Li, Y., Qian, H., Sun, X., Cui, Y., Wang, H., Du, C. and Xia, X. (2014) The Effect of Germination on Chemical Composition of Peanut Seed. Food Science and Technology Research, 20, 883-889. https://doi.org/10.3136/fstr.20.883

[37] Ayodele-Oni, O. and Enujugha, V.N. (2003) Evaluation of Nutrients and Anti-Nutrients in Lesser-Known Underutilized Oil Seeds. International Journal of Food 
Science and Technology, 38, 525-528.

https://doi.org/10.1046/j.1365-2621.2003.00698.x

[38] Pele, G.I., Ogunsua, A.O., Adepeju, A.B., Esan, Y.O. and Oladiti, E.O. (2016) Effect of Processing Method on Nutritional and Anti-Nutritional Properties of Soybeans (Glycine Max). African Journal of Food Science and Technology, 7, 9-12.

[39] Akhtar, M.S., Israr, B., Bhatty, N. and Ali, A. (2011) Effect of Cooking on Soluble and Insoluble Oxalate Content in Selected Pakistan Vegetables and Beans. International Journal of Food Properties, 14, 241-249. https://doi.org/10.1080/10942910903326056

[40] Paul, V., Verma, S. and Paul, A. (2012) Effect of Cooking and Processing Methods on Oxalate Content of Green Leafy Vegetables and Pulses. Asian Journal of Food and Agro-Industry, 5, 211-214.

[41] Kunchit, J., Somsri, C., Pongtorn, S., Kriengkrai, V. and Yupaporn, N. (2006) Total and Soluble Oxalate Contents in Thai Vegetables, Cereal Grains and Legume Seeds and Their Changes after Cooking. Journal of Food Composition and Analysis, 19, 340-347. https://doi.org/10.1016/j.jfca.2005.04.002

[42] Haron, H. and Raob, N. (2014) Changes in Macronutrient, Total Phenolic and Antinutrient Contents during Preparation of Tempeh. Journal of Nutrition and Food Science, 4, 265.

[43] Nile, S.H. and Park, S.W. (2014) Bioavailability Analysis of Oxalate and Mineral Content in Selected Edible Mushrooms. Journal of Nutritional Disorders \& Therapy, 4, 1-6.

[44] Yadav, S.K. and Sehgal S. (2003) Effects of Domestic Processing and Cooking on Selected Anti-Nutrient Contents of Some Green Leafy Vegetables. Plant Foods for Human Nutrition, 58, 1-11. https://doi.org/10.1023/B:QUAL.0000040359.40043.4f

[45] Rusydi, M.M.R. and Azrina, A. (2012) Effect of Germination on Total Phenolic, Tannin and Phytic Acid Contents in Soy Bean and Peanut. International Food Research Journal, 19, 673-677.

[46] Akinyele, B.J. and Oloruntoba, O.S. (2013) Comparative Studies on Citrullus vulgaris, Citrullus colocynthis and Cucumeropsis mannii for Ogiri Production. British Microbiology Research Journal, 3, 1-18. https://doi.org/10.9734/BMRJ/2013/2337

[47] Babalola, O.O., Tugbobo, O.S. and Daramola, A.S. (2010) Effect of Processing on the Vitamin C Content of Seven Nigerian Green Leafy Vegetables. Advance Journal of Food Science and Technology, 2, 303-305

[48] Tudor-Radu, M., Vijan, L.E., Tudor-Radu, C.M., Tita, I., Sima, R. and Mitrea, R. (2016) Assessment of Ascorbic Acid, Polyphenols, Flavonoids, Anthocyanins and Carotenoid Content in Tomato Fruits. Notulae Botanicae Horti Agrobotanici Cluj-Napoca, 44, 477-483. https://doi.org/10.15835/nbha44210332

[49] Bhuvaneswari, S., Joshi, M. and D’souza, A. (2015) Quantitative Analysis of Iron and Ascorbic Acid Content in Locally Consumed Fruits and Vegetables. International Research Journal of Biological Sciences, 4, 42-47.

[50] Yamaguchi, T., Mizobuchi, T., Kajinawa, H., Myabe, F., Terao, J., Takamura, H., and Matoba, T. (2001) Radical, Scavenging Activity of Vegetables and the Effect of Cooking on Their Activity. Food Science and Technology Resource, 7, 250-257. https://doi.org/10.3136/fstr.7.250

[51] Gautam, A.K., Bhatia, M.K. and Bhadauria. R. (2011) Diversity and Usage Custom of Plants of Western Himachal Pradesh, India-Part I. Journal of Phytology, 3, 24-36.

[52] Singh, A., Bains, K. and Kaur, H. (2016) Effect of Inclusion of Key Foods on in Vi- 
tro Iron Bioaccessibility in Composite Meals. Journal of Food Science and Technology, 54, 2033-2039. https://doi.org/10.1007/s13197-015-2154-z

[53] Brune, M., Rossander, L. and Hallberg, L. (1989) Iron Absorption and Phenolic Compounds: Importance of Different Phenolic Structures. European Journal of Clinical Nutrition, 43, 547-557.

[54] Bonsmann, G.S.S., Walczyk, T., Renggli, S. and Hurrell, R.F. (2008) Oxalic Acid Does Not Influence Nonhaem Iron Absorption in Humans: A Comparison of Kale and Spinach Meals. European Journal of Clinical Nutrition, 62, 336-341.

https://doi.org/10.1038/sj.ejcn.1602721 